\title{
Hematological and Biochemical Parameters of Cattle Declared Healthy for Slaughter at the Municipal Slaughterhouse of Korhogo (Côte d'Ivoire)
}

\author{
KAMAGATE Soualio ${ }^{1 *}$, KOKORE Angoua Baudouin ${ }^{1}$, \\ SORO Yadé René ${ }^{2}$ and YAPO Angoué Paul ${ }^{3}$
}
${ }^{1}$ Department of Animal Biology, Training and Research Unity of Biological Sciences, Peleforo Gon Coulibaly, University of Korhogo (UPGCK), Bp 1328 Korhogo, Côte d'Ivoire
${ }^{2}$ Laboratory of Biotechnology Agriculture and Valorization of the Biological Resources (LBAVRB), Department of Biosciences, Félix Houphouët-Boigny University (UFHB), Cocody Abidjan, 22 BP 582 Abidjan 22, Côte d'Ivoire
${ }^{3}$ Department of Physiology Pharmacology and Pharmacopoeia, Nangui Abrogoua University, Abidjan, 02 BP 801 Abidjan 02, Côte d'Ivoire

\section{*Corresponding author}

\section{A B S T R A C T}

Keywords

Cattle,

haematological and biochemical

parameters,

Korhogo

Article Info

Accepted:

10 September 2020

Available Online:

10 October 2020
In order to explore health status of the cattle admitted to Korhogo slaughterhouse, haematological and biochemical analyzes of these animals were performed. This study involved 67 cattle. Each cattle whole blood was collected under aseptic condition in two tubes. The first one containing EDTA and the last one anti coagulant free. These blood collections made it possible, assessment of hematological and biochemical parameters respectively. Hematological results revealed a prevalence of anemia about $31.34 \%$ in all the cattle. Similarly, females presented higher rates of abnormalities than males one. These abnormalities concerned leukocytes ( $24 \%$ vs. $5.88 \%$ ), magnesium (20\% vs. $11.76 \%$ ), calcium (98\% vs $94.12 \%$ ) and potassium (76\% vs $58.82 \%$ ). Depending on age, adults too had abnormalities rates higher than young one. These abnormalities were anemia (10.34\% vs $2.63 \%)$ and serum electrolytes deficiencies such as calcium $(100 \%$ vs 94.74\%), magnesium (20.69\% vs $18.42 \%$ ) and potassium $(72.41 \%$ vs $71.05 \%$ ). Overall, these results show that some cattle selected for this study had deficiencies which are not mentioned during inspections by health workers.

\section{Introduction}

Proteins are macromolecules made up of a variety of amino acids, some of which are essential for the human body. The body therefore necessarily needs a food supply so that it can use it for its metabolism (Dognon et al., 2018). This is why it is important to eat 
a healthy diet in which proteins intake is high enough to avoid possible deficiencies. Proteins in human diets are animal and plant origin. Between these two (02) sources of protein, animal proteins are almost complete in that they contain almost all the essential amino acids that the body needs (Laisse, 2019). The consumption of proteins of animal origin is therefore of paramount importance for humans in their quest to meet these nutritional requirements for amino acids. Animal sources include fish, eggs, chicken meat, small ruminant meat and beef (Geay et al., 2002).

Beef is one of the main suppliers in the world in terms of animal protein (Galzy and Guiraud, 2003; Goutimot, 2015). According to the FAO (2017), it was consumed in 2017 in the world, more than 10,000 kilos, or 323 million tonnes. In America, beef consumption is estimated about $84 \mathrm{~kg}$ per year per capita according to figures from the US Department of Agriculture. In Europe, in 2014 it was 10.5 $\mathrm{kg}$ per capita per year. In Africa, demand is skyrocketing especially in cities (Acardia, 2019). In Côte d'Ivoire, it is 31,470 tonnes per year (Anadolu, 2019).

Despite its high consumption, its quality in developing countries remains to be desired because veterinary inspections, authorizing slaughter, are limited to ante and post mortem inspection (Diarrassouba, 2011). However, no identified pathologies with naked eye can directly influence its quality. In contrast, in developed countries, in addition to ante and post mortem inspections, they also measure blood biological parameters (Kenny, 2010).

The shortcomings of these inspections, in Côte d'Ivoire and particularly in Korhogo, lead us to explore cattle health state declared healthy for slaughter by health workers through the analysis of biological blood parameters. In Côte d'Ivoire, little scientific researches concern the exploration of biological parameters of bovines intended for slaughter. This work at the Korhogo slaughterhouse aims to contribute in data providing.

\section{Materials and Methods}

\section{Site and study population}

This is a cross-sectional and descriptive study that led from January 10, 2019 to June 30, 2019 at the municipal slaughterhouse in Korhogo. The study included 67 cattle approved for slaughter by veterinarians.

\section{Blood samples and blood parameter assays}

Each ox blood was collected into two kinds of tube in morning about two and five hours before slaughtering. Blood collected into tubes containing EDTA was used for the determination of haematological parameters thanks to an automatic hematological analyzer of the brand "URIT 2900 Plus". Blood collected into anti-coagulant free tubes were centrifuged at $1107 \mathrm{~N}$ for 5 minutes. And then serum was used for the determination of biochemical parameters using an analyzer of the brand "RAYTO RT-9200".

\section{Statistical analyzes of haematological parameters}

The results were analysed by $\mathrm{G}$ likelihood test or log likehood ratio test using R.2.0.1 Windows version software (Ihaka and Gentleman, 1996). All data were expressed as means \pm standard error. P- values less than $5 \%$ were considered to be significant.

\section{Results and Discussion}

\section{Characterization of the study population}

The characteristics of our sampling were presented in Table 1. This table reflects the classification of animals according to age and 
sex. All the animals sampled were Zebu breed. The samples included 38 young animals ( $<4$ years) and 29 adults ( $>4$ years) corresponding $56.72 \%$, and $43.28 \%$ respectively. Seventeen animals were male and fifty female corresponding $25.37 \%$ and $74.63 \%$ respectively.

\section{Analysis of haematological parameters and some minerals of the cattle}

Table 2 shows the different proportions of cattle according to their health status. According to the results shown in this table, 21 cattle or $31.34 \%$ of the subjects presented an anomaly in the hemoglobin level. On the other hand, 46 cattle or $68.65 \%$ showed a normal level of hemoglobin. Concerning leukocytes, an abnormal level was recorded in 13 cattle, or $19.40 \%$ against 54 cattle which had a normal level or $80.60 \%$.

In terms of calcium, 2 cattle corresponding $2.99 \%$ of cattle had a normal level of calcium while 65 cattle or $97.01 \%$ of the subjects presented an abnormal level. For magnesium, 55 cattle or $82.05 \%$ of the cattle had a normal level while 12 cattle or $17.91 \%$ showed an abnormal level. As for serum potassium, 19 cattle or $28.36 \%$ of cattle had a normal rate against 48 cattle, or $71.64 \%$ of subjects who presented an abnormal rate.

\section{Variation of haematological parameters and some minerals in study cattle depending on sex}

Presented in Table 3, the different proportions of the blood parameters of cattle according to sex according to their state of health showed no significant difference ( $p>0.05$ ) between the two sexes. On the other hand, a statistically significant difference $(p=0.0006)$ was observed in the sick animals in the level of leukocytes. This rate was significantly high in 12 females, or $24 \%$, compared to the rate observed in one (1) male, or $5.88 \%$. For hemoglobin, females reported higher levels of normal subjects compared to males (35 females or $70 \%$ vs. 11 males or $64.75 \%$ ). In addition, the males, 6 in number, i.e. $35.25 \%$, had an abnormal hemoglobin level compared with 35 females, i.e. $30 \%$. In terms of leucocytes, the males, numbering 16, presented $94.12 \%$ of normal subjects against $76 \%$ in 38 females. Conversely, females, numbering 12, showed abnormal levels in $24 \%$ compared to $5.88 \%$ in one (1) males.

As with the haematological parameters, No significant difference ( $p>0.05$ ) between healthy subjects and sick subjects in biochemical parameters was observed.

As with the haematological parameters, No significant difference ( $p>0.05$ ) between healthy subjects and sick subjects in biochemical parameters was observed.

In contrast, healthy animals for potassium ion showed a statistically significant difference $(\mathrm{p}$ $=0.03$ ). For calcium ion, males showed a high rate of normal subjects compared to females (1 male or $5.88 \%$ against 1 female or $2 \%$ ). Conversely, females numbering 49 , or $98 \%$, exhibited a high rate of abnormal subjects compared to males, numbering 16 , or $94.12 \%$.

\section{Variation of haematological parameters and some minerals in study cattle according to age}

Table 4 shows the proportions of young and adult cattle. Based on the results reported in this table, no significant difference ( $p>0.05$ ) was observed between normal and abnormal subjects. Adults numbering 20, or $68.97 \%$, had a normal high hemoglobin level compared to young people, numbering 26 , or $68.4 \%$. Conversely, young people with a population of 12 or $31.58 \%$, had an abnormal high hemoglobin level compared to 9 adults, or $30.63 \%$. 
Regarding the level of leukocytes, 31 young people or $81.58 \%$ presented more normal subjects compared to 22 adults or $75.86 \%$.

For calcium ion, only 2 young people, or $5.26 \%$ had a level of normal subjects. On the other hand, in all adults this rate was abnormal.
In terms of the levels of magnesium and potassium ions, the young people respectively presented high levels of normal subjects compared to adults (31 young people or $81.58 \%$ against 23 adults or $79.31 \%)$ and (11 young people or $28.95 \%$ against 8 adults, or $27.59 \%)$.

Table.1 Characteristics data for cattle

\begin{tabular}{|l|lr|}
\hline Characteristics & \multicolumn{2}{|c|}{$\begin{array}{c}\text { Total cattle } \\
(\mathbf{N}=67)\end{array}$} \\
\hline Age (years) & $\mathrm{n}$ & $\%$ \\
\hline$\quad$ Youth (age <4 years) & 38 & 56.72 \\
\hline$\quad$ Adults (age $>$ 4 years) & 29 & 43.28 \\
\hline Sex & & 25.37 \\
\hline$\quad$ Males & 17 & 74.63 \\
\hline$\quad$ Females & 50 & 100 \\
\hline Race & & \\
\hline Zebu & 67 & \\
\hline
\end{tabular}

N: Total number of cattle; n: Number observed for each characteristic; \%: Percentage.

Table. 2 Proportions of all cattle according to their health status after analysis of haematological parameters

\begin{tabular}{|l|c|c|c|c|c|c|}
\hline Blood parameters & $\begin{array}{c}\text { Normal } \\
\text { values }\end{array}$ & $\mathbf{N}$ & \multicolumn{2}{|c|}{ Normal } & \multicolumn{3}{|c|}{ Abnormal } \\
\hline Hemoglobin (g/dl) & & & $\mathrm{n}$ & $\%$ & 21 & $\%$ \\
\hline & $8-12$ & 67 & 46 & 68.65 & & 31.34 \\
\hline $\begin{array}{l}\text { Leucocytes (10\%) } \\
\boldsymbol{\mu l})\end{array}$ & $4-12$ & 67 & 54 & 80.60 & 13 & 19.40 \\
\hline $\mathbf{C a}^{\mathbf{2 +}}(\mathbf{m g} / \mathbf{L})$ & $80-100$ & 67 & 2 & 2.99 & 65 & 97.01 \\
$\mathbf{M g}^{\mathbf{2 +}} \mathbf{( m g / L )}$ & $17-218$ & 67 & 55 & 82.5 & 12 & 17.98 \\
$\mathbf{K}^{+}(\mathbf{m m o l} / \mathbf{L})$ & $4-5$ & 67 & 19 & 28.36 & 48 & 71.64 \\
\hline
\end{tabular}

N: Total number of cattle; n: Numbers observed in each group of cattle; \%: Percentage. 
Table.3 Variation of blood parameters in male and female cattle depending on their state of health

\begin{tabular}{|c|c|c|c|c|c|}
\hline Blood parameters & \multicolumn{2}{|c|}{ Males $(\mathbf{N}=17)$} & \multicolumn{2}{|c|}{ Females $(\mathbf{N}=\mathbf{5 0})$} & \multirow[t]{2}{*}{$\mathbf{p}$} \\
\hline Hemoglobin (g/dl) & $\mathrm{n}$ & $\%$ & $\mathrm{n}$ & $\%$ & \\
\hline Normaux (8-12) & 11 & 64.75 & 35 & 70 & $0.65(\mathrm{NS})$ \\
\hline Anormaux $(<8$ et $>12)$ & 6 & 35.25 & 15 & 30 & $0.51(\mathrm{NS})$ \\
\hline \multicolumn{6}{|l|}{ Leucocytes $\left(10^{3} / \mu \mathrm{L}\right)$} \\
\hline Normal (4-12) & 16 & 94.12 & 38 & 76 & $0.16(\mathrm{NS})$ \\
\hline Abnormal $(<4$ et $>12)$ & 1 & 5.88 & 12 & 24 & $0.0006(\mathrm{~S})$ \\
\hline \multicolumn{6}{|l|}{$\mathrm{Ca}^{2+}(\mathrm{mg} / \mathrm{L})$} \\
\hline Normal (8-100) & 1 & 5.88 & 1 & 2 & $0.16(\mathrm{NS})$ \\
\hline Abnormal $(<80$ et $>100)$ & 16 & 94.12 & 49 & 98 & $0.78(\mathrm{NS})$ \\
\hline \multicolumn{6}{|l|}{$\mathrm{Mg}^{2+}(\mathrm{mg} / \mathrm{L})$} \\
\hline Normal (17-218) & 15 & 88.24 & 40 & 80 & $0,53(\mathrm{NS})$ \\
\hline Abnormal $(<17$ et $>218)$ & 2 & 11.76 & 10 & 20 & $0.14(\mathrm{NS})$ \\
\hline \multicolumn{6}{|l|}{$\mathbf{K}^{+}(\mathbf{m m o l} / \mathbf{L})$} \\
\hline Normal (4-5) & 7 & 41.18 & 12 & 24 & $0.03(\mathrm{~S})$ \\
\hline Abnormal $(<4$ et $>5)$ & 10 & 58.82 & 38 & 76 & $0.14(\mathrm{NS})$ \\
\hline
\end{tabular}

$\mathrm{N}$ : Total number of cattle by sex; n: Numbers observed in each group of cattle; \%: Percentage;

S: Statistically significant difference for $\mathrm{p}<0.05$; NS: Non-significant difference for $\mathrm{p}>0.05$.

Table.4 Comparative proportions of blood parameters in young and adult cattle according to their state of health

\begin{tabular}{|c|c|c|c|c|c|}
\hline Blood parameters & \multicolumn{2}{|c|}{ Young $(\mathbf{N}=38)$} & \multicolumn{2}{|c|}{ Adults $(\mathbf{N}=29)$} & \multirow[t]{2}{*}{$\mathbf{p}$} \\
\hline Hemoglobin (g/dl) & $\mathrm{n}$ & $\%$ & $\mathrm{n}$ & $\%$ & \\
\hline Normaux (8-12) & 26 & 68.42 & 20 & 68.97 & $0.96(\mathrm{NS})$ \\
\hline Anormaux $(<8$ et $>12)$ & 12 & 31.58 & 9 & 30.63 & $0.90(\mathrm{NS})$ \\
\hline \multicolumn{6}{|l|}{ Leucocytes $\left(10^{3} / \mu \mathrm{L}\right)$} \\
\hline Normal (4-12) & 31 & 81.58 & 22 & 75.86 & $0.90(\mathrm{NS})$ \\
\hline Abnormal $(<4$ et $>12)$ & 7 & 18.42 & 7 & 24.13 & $0.90(\mathrm{NS})$ \\
\hline \multicolumn{6}{|l|}{$\mathrm{Ca}^{2+}(\mathrm{mg} / \mathrm{L})$} \\
\hline Normal (8-100) & 2 & 5.26 & - & - & $0.90(\mathrm{NS})$ \\
\hline Abnormal $(<80$ et $>100)$ & 36 & 94.74 & 29 & 100 & $0.90(\mathrm{NS})$ \\
\hline \multicolumn{6}{|l|}{$\mathrm{Mg}^{2+}(\mathrm{mg} / \mathrm{L})$} \\
\hline Normal (17-218) & 31 & 81.58 & 23 & 79.31 & $0.90(\mathrm{NS})$ \\
\hline Abnormal $(<17$ et $>218)$ & 7 & 18.42 & 6 & 20.69 & $0.90(\mathrm{NS})$ \\
\hline \multicolumn{6}{|l|}{$\mathrm{K}^{+}(\mathrm{mmol} / \mathrm{L})$} \\
\hline Normal (4-5) & 11 & 28.95 & 8 & 27.59 & $0.90(\mathrm{NS})$ \\
\hline Abnormal $(<4$ et $>5)$ & 27 & 71.05 & 21 & 72.41 & $0.90(\mathrm{NS})$ \\
\hline
\end{tabular}

$\mathrm{N}$ : Total number of cattle by age; $\mathrm{n}$ : Numbers observed in each group of cattle; \%: Percentage;

S: Statistically significant difference for $p<0.05$; NS: Non-significant difference for $p>0.05$ 
At the level of magnesium and potassium ions, the males presented respectively high levels of normal subjects $(88.24 \%$ against $80 \%$ ) and (41.18\% against $24 \%$ ) compared to the females. Conversely, females exhibited elevated levels of abnormal subjects (20\% vs. $11.76 \%)$ for magnesium ion and (76\% vs. $58.82 \%$ ) for potassium ion compared to males.

The analysis of haematological and biochemical parameters to judge the state of health of the cattle in addition to the inspections made is very important. It allows detection of pathologies not identified with the naked eye that can directly influence the quality of beef.

To verify this state of affairs, a study was carried out on the analysis of certain biological blood parameters in 67 cattle declared healthy by health workers at the Korhogo slaughterhouse. To This study was carried out in order to assess some biological blood parameters in 67 cattle declared healthy by health workers at the Korhogo slaughterhouse Haematological parameters such as haemoglobin and leukocytes, serum electrolytes such as calcium, magnesium and potassium were analysed.

Analysis of these parameters revealed that the prevalence of anemia in these cattle was $30 \%$. This prevalence of anemia in cattle would have been due to a deficiency of some elements promoting the synthesis of red blood cells such as iron and vitamin B12, or an excessive destruction of red blood cells (Bagnara et al., 1991).

According to some authors, anemia is linked to the presence of ticks on these animals and the immune system of young cattle is weaker than that of adults (Friot and Calvet, 1973; Boubet and Guerin, 2019).
This failure in young people is thought to be due to diseases and infections, which cause damage to lymphocytes.

In the present, depending on the sex, the abnormal value of the leukocyte rate in females was significantly higher than the rate observed in males $(24 \%$ vs. $5.88 \%$ respectively). These abnormalities seen in the leukocytes could be leukopenia or leukocytosis. They can also be due to a bone marrow pathology. Indeed, the bone marrow being affected, the stem cells that are produced there, at the origin of the production of blood cells can no longer be produced. Consequently, a deficiency is created in the affected subjects and this can cause serious consequences. Our results are superimposable on those obtained Calvo et al., (1989). According to the work carried out by these authors, the significant decrease in leukocytes is due to parasitic infections.

These investigations revealed that the high prevalence of anomalous calcium values was the main observation. Indeed, more than $90 \%$ of the cattle had an abnormal rate. The causes of this abnormality are thought to be due to malignant pathologies often associated with bone metastases or primary hyperthyroidism or vitamin $\mathrm{D}$ intoxication, and rarely to infections such as tuberculosis (Marshall and Bangert, 2005).

Furthermore, the prevalence of abnormal potassium values was observed in this study. In all cattle this prevalence was $71.64 \%$. This prevalence observed in this study is higher than that obtained by Radostits et al., (2000). The prevalence of abnormal potassium values observed in their study was $58.82 \%$. According to these authors, this degradation of potassium in cattle is due to digestive or renal losses and could have more frequent effects, the most serious of which are tachycardia, cardiac rhythm disorders and 
digestive disorders (parasite infestation, infection bacterial or viral, ulcers, etc.). In the same sense, according to the work of Martinez et al., (2012) this degradation of potassium would be linked to the reduced number of neutrophil granulocytes circulating in the blood.

In conclusion, the exploration study of blood parameters in cattle selected at the Korhogo slaughterhouse made it possible to assess the health status of the cattle declared healthy. Most of these cattles admitted for slaughter had hematological and biochemical disorders. Haematological disorders were characterized by anemia and leukocyte disorders.

And biochemical disorders were characterized by high prevalence of abnormal values of calcium and potassium. These disorders could affect beef quality as they reduce some nutrients necessary for human good health. In order to improve beef quality, veterinary inspections before slaughtering should include biological parameters exploration. This study should be also performed in many slaughterhouses in the Savannah district, the first cattle stock farming area in Côte d'Ivoire.

\section{Acknowledgements}

We would like to thank the Regional Director of the Ministry of Animal and Fisheries Resources in the person of Mr. COULIBALY Bessientie for authorizing such a study in the municipal slaughterhouse of Korhogo. We also express our thanks to Dr KOUADIO Emile for advices during the manuscript's drafting of this investigation.

\section{Funding}

This research did not receive any specific grant from any funding agency in the public, commercial, or not-for-profit sector.

\section{Authors' contributions}

All authors contributed equally in the study. They made substantial contributions to the design of the study, the collection of the data as well as the preparation and analysis of the data. They also drafted the manuscript and gave final approval for its submission to the journal for consideration of publication.

\section{Conflict of interest}

The authors declare that there is no conflict of interest that could be perceived as prejudicing the impartiality of the research reported.

\section{References}

Acardia, 2019. Viande : l'Afrique de plus en plus dépendante des importations. Rapport sur le commerce des matières premières en Afrique, 32p.

Anadolu, 2015. Viandes rouges : la Côte d'Ivoire veut réguler un marché dominé par les importations. Rapport sur la viande locale, $58 \mathrm{p}$.

Bagnara G. P., Zauli G., Re M. C., Furlini G., Giovannini M., Ranieri S., Brizzi M. F. Boubet B. et Guerin D. 2019. Maladies sanguines liées aux tiques. Piroplasmose, anaplasmose. https://www.pleinchamp.com/elevage/a ctualites/maladies-sanguines-liees-auxtiques.-piroplasmose-anaplasmose. Consulté le 14/07/2020.

Calvo J. J., Cadet J., Bellon S., Berger M., Bourdat A.G., Douki T., Duarte V., Allue, J. R., Eesudeso A., Garcia L. J. (1989). Plasma ferritin of sows during pregnancy and lactation. Cornell Veterinary, 79: 273-282.

Diarrassouba A. K. 2011. Etude diagnostiques des conditions de préparation et d'inspection des viandes de boucherie aux abattoirs du district d'Abidjan. 
Thèse de médecine vétérinaire, Dakar, $172 \mathrm{p}$.

Djakaridja B., Yao P. K., Gragnon B. G., Acapovi G. Y., Mavoungou J. F., N'goran E.K. 2014. Situation épidémiologique des hémoparasites des bovins dans deux zones d'élevage de la Côte d'Ivoire: Cas des anciennes régions des savanes et de la vallée du Bandama. Revue Médecine Vétérinaire, 165 : 9-10-303.

Evaluation of peripartal calcium statuts, energetic profile, and neutrophil function in dairy cows at low or high risk of developing uterine disease. Journal of Dairy Science, 95: 71587172.

FAO, 2017. Perspectives agricoles de l'OCDE et de la FAO. Editions OCDE, Paris, 42(3): 158 p.

Friot D. and Calvet H. 1973. Biochnnie et élevage au Sénégal. Revue Elevage Médical vétérinaire Pays tropical, 26 : 75-96.

Galzy P. and Guiraud J. 2003. L'analyse microbiologique dans les industries agroalimentaires. Edition de l'usine nouvelle, France, $233 \mathrm{p}$.

Goutimot, 2015. Elevage en côte d'Ivoire : typologie et performance. Revue Elevage traditionnel, 10: 45-50.

Ihaka R. and Gentleman R., 1996. R: a language for data analysis and graphics. Journal of computational and graphistatist, 5(3): 299-314.

Kenny M., (2010). Hématologie des bovins : Etude des variations de la naissance à 60 jours. Ecole Nationale Vétérinaire de Lyon, Thèse $\mathrm{n}^{\circ} 80,163 \mathrm{p}$.

La Placa M. 1991. Impaired GM-CSF production by cultured light density monoclear cells and $\mathrm{T}$ lymphocytes correlates with the number of circulating in HIV-1 seropositive subjects. Journal Cellule Cloning. 9: 239.

Marshall W.J., Bangert S.K. 2005. Clinical Chemistry, 5th Ed. Elsevier, London, UK, 392p.

Martinez N., Risco C. A., Lima F.S., Bisinotto R. S., Grego L. F. and Riberro E. S. 2012.

Radostits O.M., Blood D.C., Gay C.C., Kenneth W.H. 2000. Veterinary Medicine: A textbook of the diseases of Cattle, Sheep, Pigs, Goats and Horses, $9 \mathrm{t}$ h Edition].

\section{How to cite this article:}

KAMAGATE Soualio, KOKORE Angoua Baudouin, SORO Yadé René and YAPO Angoué Paul. 2020. Hematological and Biochemical Parameters of Cattle Declared Healthy for Slaughter at the Municipal Slaughterhouse of Korhogo (Côte d'Ivoire). Int.J.Curr.Microbiol.App.Sci. 9(10): 1065-1072. doi: https://doi.org/10.20546/ijcmas.2020.910.127 